\title{
Optimasi Kondisi Sintesis Asam 4-Benzoiloksisinamat Menggunakan Iradiasi Gelombang Mikro
}

Ilham Bagus Sagitaras, Achmad Syahrani, Juni Ekowati*

Departemen Kimia Farmasi, Fakultas Farmasi, Universitas Airlangga, Surabaya

*Corresponding author: j_ekowati@yahoo.com

Submitted: 7 Mei 2019

Accepted: 25 Juli 2019

Published online: 31 Juli 2019

\begin{abstract}
Background: One of the efforts to improve the activity of p-coumaric acid, is to increase its lipophylicity. The benzoylation reaction on the phenolic moiety of p-coumaric acid is one of the strategy to increase its lipophylicity. Microwave irradiation is an alternative method to increase the efficiency of the organic reaction. Beside having the advantage of accelerating chemical reactions, the use of microwave irradiation can also cause degradation of the desired product and rise of other side reactions. Objectives : to optimize the condition of the benzoylation reaction in the phenolic moiety of p-coumaratic acid using microwave irradiation. Methods: The reaction was performed using microwave oven at power irradiation: 180, 270, and 360 Watt, by reacting p-coumaric acid, benzoyl chloride, and pyridine as catalysts to produce the 4-benzoyloxycinnamic acid. The completion of the reaction was determined by TLC every 30 seconds reaction time. The characterization of 4benzoyloxycinnamic acid was performed using UV-Vis, FT-IR and ${ }^{l} H-N M R$ spectrometry. Results: The yield of product at 180, 270, and 360 Watt consecutively were 49.3\%, 58.5\%, and $47.7 \%$. There was significant difference between the percentage yields at 180 and 270 Watt; and between yield at 270 and $360 \mathrm{Watt}$, but there was no significant difference between the yield at 180 and 360 Watt. The highest yield reaction was obtained at 270 Watt was $61.4 \%$. Reaction conducted over sixty seconds caused degradation of the product. Conclusion: Optimum condition benzoylation reaction p-coumaric acid to produce 4-benzoyloxycinnamic acid is one minute at 270 Watt power of microwave irradiation.
\end{abstract}

Keywords: 4-benzoyloxycinnamic acid, microwave, power of irradiation, p-coumaric acid, nucleuphylic acyl substitution

\begin{abstract}
Abstrak
Pendahuluan: Salah satu usaha meningkatkan aktivitas asam $p$-kumarat adalah meningkatkan sifat lipofiliknya. Reaksi benzoilasi gugus fenol asam $p$-kumarat merupakan salah satu strategi meningkatkan sifat lipofilik. Iradiasi microwave merupakan salah satu alternative metode untuk meningkatkan efisiensi dalam reaksi organik. Selain memiliki kelebihan mempercepat reaksi kimia, penggunaan iradiasi gelombang mikro juga dapat menyebabkan kerusakan struktur kimia produk maupun terjadinya reaksi samping lainnya. Tujuan: Mendapatkan kondisi optimum reaksi sintesis asam 4-benzoiloksisinamat. Metode: asam 4-benzoiloksisinamat disintesis dengan cara mereaksikan asam $p$-kumarat, benzoil klorida dan piridin sebagai katalis. Reaksi benzoilasi dilakukan dengan iradiasi gelombang mikro pada daya 180, 270, dan 360 Watt. Karakterisasi asam 4benzoiloksisinamat dilakukan menggunakan alat spektrometer UV-Vis, FT-IR dan ${ }^{1} \mathrm{H}-\mathrm{NMR}$. Hasil: Persentase hasil yang diperoleh pada daya 180, 270, dan 360 Watt berturut-turut adalah sebagai berikut 49,3\%, 58,5\%, and $47,7 \%$. Terdapat perbedaan yang signifikan persentase hasil yang diperoleh pada daya 270 Watt dengan persentase hasil pada daya 180 Watt dan 360 Watt, tetapi tidak ada perbedaan bermakna persentase hasil pada daya 180 Watt dan 360 Watt. Persentase hasil terbesar diperoleh selama enam puluh detik pada daya 270 Watt, yaitu $61,4 \%$. Jika reaksi dilakukan lebih dari enam puluh detik, terjadi kerusakan struktur senyawa target.
\end{abstract}


Kesimpulan: Kondisi optimum sintesis asam 4-benzoiloksisinamat menggunakan iradiasi gelombang mikro adalah selama enam puluh detik pada daya 270 Watt.

Kata Kunci: asam 4-benzoiloksisinamat, microwave, daya iradiasi gelombang mikro, asam $p$-kumarat

\section{PENDAHULUAN}

Asam $p$-kumarat adalah salah satu derivat senyawa asam sinamat yang dilaporkan dapat berfungsi sebagai agen anti inflamasi. Asam $p$-kumarat berfungsi sebagai agen anti inflamasi dengan menurunkan ekspresi inducible Nitric Oxide Synthase (iNOS), COX-2, IL$1 \beta$, dan TNF- $\alpha$ pada mRNA dan/atau kadar protein dalam sel RAW 264,7 yang distimulasi oleh LPS. Asam $p$-kumarat juga dapat menurunkan kadar sitokin (Zhao dkk., 2016).

Berdasarkan strukturnya, asam $p$-kumarat memiliki satu cincin aromatis, satu gugus - $\mathrm{OH}$ fenolik, satu ikatan karbon rangkap dua $(\mathrm{C}=\mathrm{C})$, dan satu gugus karboksilat. Dari keempat gugus tersebut, terdapat dua gugus farmakofor yang berperan dalam aktivitas antiinflamasinya, yaitu gugus karboksilat dan cincin aromatis (Neophytou dkk., 2011; Caseley dkk., 2015).

Berdasarkan data dengan program ChemBioDraw Ultra $12.0 ®$, asam $p$-kumarat memiliki nilai $\log \mathrm{P}$ sebesar 1,54. Nilai $\log \mathrm{P}$ tersebut yang lebih rendah dibandingkan dengan nilai $\log P$ membran semipermeabel dalam tubuh ( $\log \mathrm{P}=2-3)$ sehingga diperlukan suatu upaya untuk meningkatkan nilai $\log \mathrm{P}$ agar daya penetrasi terhadap membran semipermeabel meningkat dan aktivitas dapat meningkat. Salah satu upaya yang dilakukan dalam penelitian ini untuk meningkatkan aktivitas antiinflamasi dari asam $p$ kumarat yaitu dengan melakukan reaksi esterifikasi pada gugus $-\mathrm{OH}$ fenolik. Penggantian gugus tersebut dapat meningkatkan sifat hidrofobik senyawa tersebut sehingga proses penembusan membran semipermeabel dalam tubuh akan menjadi lebih mudah (Ekowati dkk., 2017).

Sehubungan dengan usaha meningkatkan lipofilitas senyawa asam $p$-kumarat, dilakukan perubahan gugus $\mathrm{OH}$ fenolik menjadi gugus ester melalui reaksi substitusi asil nukleofilik. Pada penelitian ini gugus $-\mathrm{OH}$ fenolik asam $p$-kumarat direaksikan dengan suatu senyawa asil halida.

Asil halida merupakan derivat asam karboksilat yang paling reaktif dibandingkan dengan derivat ester lainnya sehingga reaksi antara asil halida dengan alkohol berjalan lebih cepat dibandingkan reaksi esterifikasi lainnya (Solomon dkk., 2016).
Pada penelitian ini digunakan katalis basa organik yaitu piridina. Piridina memiliki nilai $\mathrm{p}_{\mathrm{Kb}}$ sebesar 8,75 (Quellette \& Rawn, 2014). Piridina memiliki struktur planar dan pasangan atom bebas pada $\mathrm{N}$ tidak ikut dalam resonansi sehingga piridina merupakan katalis basa yang efektif (Putra dkk., 2017). Sebagai katalis, piridina mempercepat reaksi melalui pembentukan ion asilpiridinium yang nantinya akan bereaksi dengan alkohol atau fenol. Piridina selanjutnya akan mengikat hasil samping $\mathrm{HCl}$ membentuk suatu garam yang larut dalam air (Carey \& Sundberg, 2001).

Iradiasi gelombang mikro digunakan sebagai sumber energi pada reaksi ini. Iradiasi gelombang mikro pada dasarnya adalah iradiasi gelombang elektromagnetik yang saat ini banyak diterapkan dalam sintesis senyawa organik. Metode ini memiliki beberapa keunggulan, antara lain laju pemanasan yang lebih cepat sehingga mengakibatkan berkurangnya waktu reaksi, produk yang dihasilkan lebih banyak, pemanasannya seragam, selektif (didasarkan pada respon suatu bahan terhadap gelombang mikro), ramah lingkungan, dan reprodusibilitas lebih baik (Ameta dkk., 2015).

Tujuan penelitian ini yaitu untuk mengetahui pengaruh daya pada proses iradiasi gelombang mikro terhadap persentase hasil sintesis senyawa asam 4benzoiloksisinamat yang didapatkan pada Gambar 1 .<smiles>O=C(O)/C=C/c1ccc(OC(=O)c2ccccc2)cc1</smiles>

Gambar 1. Asam 4-O-benzoiloksisinamat

Penggunaan iradiasi gelombang mikro dapat mempercepat laju reaksi karena energi yang dipancarkan oleh oven gelombang mikro tersebut dapat meningkatkan jumlah tumbukan-tumbukan yang terjadi pada molekul-molekul senyawa polar. Jumlah energi yang dipancarkan oleh oven gelombang mikro tersebut tergantung pada daya yang digunakan. Semakin besar daya yang dikeluarkan, maka semakin besar pula energi yang dipancarkan oleh oven gelombang mikro (Grundas, 2011). 


\section{BAHAN DAN METODE}

\section{Bahan}

Asam p-kumarat (Sigma-Aldrich $\AA$ ), Benzoil klorida p.a (Merck®), Tetrahidrofuran p.a (Merck®), Piridina p.a (Merck®), $n$-Heksana p.a (Merck®), Etil asetat p.a (Merck®), Kloroform p.a (Merck®), Asam formiat p.a (Merck®), Asam klorida p.a (Merck®), Metanol p.a (Merck®), Silica gel 60 (Merck®), dan lempeng KLT silica gel GF254 (Merck®).

Alat

Neraca analitik Sartorius ${ }^{\circledR} \quad$ BL-600, Sharp® Microwave oven R-728(S)-In (Spesifikasi: daya 900 watt, kapasitas maksimum $25 \mathrm{~L}$, dan power source 220 - 240 Volt), lampu UV $254 \mathrm{~nm}$, pengukur titik lebur (Electrothermal Melting Point Apparatus ${ }^{\circledR}$ ), spektrofotometer FT-IR (Perkin Elmer® Spektrum One), spektrofotometer UV-Vis (Hitachi ${ }^{\circledR} \mathrm{UH} 5300$ ), dan spektrofotometer FT-NMR Jeol® ECS $400 \mathrm{MHz}$ (dilakukan di ITD UNAIR), aplikasi IBM SPSS Statistics 24.

\section{Metode}

\section{Optimasi kondisi sintesis}

Asam kumarat sebanyak $200 \mathrm{mg}(1,22 \mathrm{mmol})$ dilarutkan dalam tetrahidrofuran $0,5 \mathrm{~mL}(6,21 \mathrm{mmol})$, benzoil klorida sebanyak $0,3 \mathrm{~mL}(2,58 \mathrm{mmol})$ dan $0,5 \mathrm{~mL}$ piridina dalam kondis dingin. Campuran direaksikan dalam oven gelombang mikro pada daya 180, 270, dan 360 watt dan waktu diatur selama 30 detik tiap satu kali iradiasi.

\section{Uji kesempurnaan reaksi}

Menggunakan Kromatografi Lapis Tipis (KLT)Densitometri dengan baku pembanding yaitu asam kumarat dan asam benzoat, dan fase gerak yang digunakan adalah campuran eluen kloroform : etil asetat $=9: 1$.

\section{Uji kualitatif $\mathbf{O H}-f e n o l i k$}

Senyawa hasil sintesis ditetesi dengan pereaksi $\mathrm{FeCl}_{3}$ dan diamati warna yang terbentuk. Pembandingnya adalah asam $p$-kumarat.

\section{Tahap pemisahan senyawa hasil sintesis}

Campuran hasil sintesis ditambahkan larutan $\mathrm{HCl}$ $2 \mathrm{~N}$ hingga suasana asam dan terbentuk endapan. Endapan tersebut disaring dengan corong Buchner, dan dilakukan proses pemurnian dengan kromatografi kolom. Fase diam silika gel 60 (Merck), fase gerak kloroform : etil asetat (9:1).

\section{Uji kemurnian senyawa hasil sintesis}

\section{Uji kemurnian dengan penentuan jarak lebur}

Pengujian kemurnian senyawa hasil sintesis dengan penentuan jarak lebur dilakukan dengan menggunakan alat Electrothermal Melting Point
Apparatus. Dilakukan pengamatan saat serbuk terlihat mulai melebur hingga seluruh bagian kristal melebur sempurna.

\section{Uji kemurnian dengan KLT}

Sedikit senyawa hasil sintesis dilarutkan dalam kloroform kemudian ditotolkan pada plat silica gel GF254. Sebagai pembanding, digunakan asam kumarat dan asam benzoat. Uji Kemurnian ini dilakukan dengan menggunakan tiga eluen yang berbeda. Eluen yang digunakan antara lain $n$-heksana : kloroform : asam formiat $=19: 20: 1$, kloroform $:$ etil asetat $=9: 1$, dan kloroform : etil asetat : metanol $=50: 50: 1$. Setelah itu dilakukan pengamatan noda di bawah lampu sinar UV $254 \mathrm{~nm}$.

\section{Identifikasi struktur senyawa}

\section{Identifikasi dengan spektrofotometri UV}

Sejumlah tertentu senyawa hasil sintesis dilarutkan dalam kloroform dan diukur serapannya dengan spektrofotometer UV-Vis pada panjang gelombang 200 - $400 \mathrm{~nm}$. Lalu diamati bentuk spektrum yang terekam dan panjang gelombang maksimalnya.

\section{Identifikasi dengan spektrofotometri FTIR}

Sejumlah kecil senyawa hasil sintesis digerus bersama dengan serbuk kering $\mathrm{KBr}$ dalam mortir agat. Kemudian campuran tersebut dimasukkan ke dalam alat pencetak pelet dan dilakukan pencetakan hingga diperoleh pelet yang transparan. Pelet yang terbentuk diletakkan dalam sample holder dan dilakukan scanning dengan spektrofotometer FT-IR.

\section{Identifikasi dengan spektrometri ${ }^{\mathbf{1}} \mathbf{H}$-NMR}

Sejumlah kecil senyawa hasil sintesis dilarutkan dalam kloroform kemudian ditambahkan TMS (di dalam $5 \mathrm{~mm}$ o.d. glass tube) kemudian diletakkan dalam sample holder. Diamati dan dianalisis spektrum resonansi magnet proton yang terekam.

\section{HASIL DAN PEMBAHASAN}

Sintesis antara asam $p$-kumarat dan benzoil klorida dengan katalis piridin menggunakan iradiasi gelombang mikro pada daya 180 Watt, 270 Watt, dan 360 Watt telah berhasil dilakukan (Gambar 2). Hasil yang diperoleh dengan uji KLT dapat dilihat pada Tabel 1.

Berdasarkan Tabel 1, dapat diketahui bahwa terdapat 4 noda pada senyawa hasil sintesis. Noda dengan nilai $\mathrm{Rf}=0,09$ adalah noda dari asam $p$ kumarat, noda dengan nilai $\mathrm{Rf}=0,17$ adalah noda dari asam benzoat, noda dengan nilai $\mathrm{Rf}=0,54$ adalah noda dari benzoil klorida, dan noda dengan nilai $\mathrm{Rf}=0,89$ adalah noda dari senyawa target. 
Tabel 1. Hasil uji KLT senyawa hasil sintesis

\begin{tabular}{|c|c|c|c|c|}
\hline Daya (Watt) & Waktu & Jumlah Noda & $\mathrm{Rf}$ & Intensitas Relatif Noda (Visual) \\
\hline \multirow{16}{*}{180} & \multirow{4}{*}{$0 \times 30$} & \multirow{4}{*}{4 noda } & 0,09 & ++ \\
\hline & & & 0,17 & + \\
\hline & & & 0,54 & ++ \\
\hline & & & 0,89 & +++ \\
\hline & \multirow{4}{*}{$1 \times 30$} & \multirow{4}{*}{4 noda } & 0,09 & ++ \\
\hline & & & 0,17 & + \\
\hline & & & 0,54 & ++ \\
\hline & & & 0,89 & +++ \\
\hline & \multirow{4}{*}{$2 \times 30$} & \multirow{4}{*}{4 noda } & 0,09 & ++ \\
\hline & & & 0,17 & + \\
\hline & & & 0,54 & ++ \\
\hline & & & 0,89 & +++ \\
\hline & \multirow{4}{*}{$3 \times 30$} & \multirow{4}{*}{4 noda } & 0,09 & ++ \\
\hline & & & 0,17 & + \\
\hline & & & 0,54 & ++ \\
\hline & & & 0,89 & +++ \\
\hline \multirow{16}{*}{270} & \multirow{4}{*}{$0 \times 30$} & \multirow{4}{*}{4 noda } & 0,09 & ++ \\
\hline & & & 0,17 & + \\
\hline & & & 0,54 & ++ \\
\hline & & & 0,89 & +++ \\
\hline & \multirow{4}{*}{$1 \times 30$} & \multirow{4}{*}{4 noda } & 0,09 & ++ \\
\hline & & & 0,17 & + \\
\hline & & & 0,54 & ++ \\
\hline & & & 0,89 & +++ \\
\hline & \multirow{4}{*}{$2 \times 30$} & \multirow{4}{*}{4 noda } & 0,09 & ++ \\
\hline & & & 0,17 & + \\
\hline & & & 0,54 & ++ \\
\hline & & & 0,89 & +++ \\
\hline & \multirow{4}{*}{$3 \times 30$} & \multirow{4}{*}{4 noda } & 0,09 & ++ \\
\hline & & & 0,17 & + \\
\hline & & & 0,54 & ++ \\
\hline & & & 0,89 & +++ \\
\hline \multirow{10}{*}{360} & \multirow{4}{*}{$0 \times 30$} & \multirow{4}{*}{4 noda } & 0,09 & ++ \\
\hline & & & 0,17 & + \\
\hline & & & 0,54 & ++ \\
\hline & & & 0,89 & +++ \\
\hline & \multirow{4}{*}{$1 \times 30$} & \multirow{4}{*}{4 noda } & 0,09 & ++ \\
\hline & & & 0,17 & + \\
\hline & & & 0,54 & ++ \\
\hline & & & 0,89 & +++ \\
\hline & \multirow{2}{*}{$2 \times 30$} & \multirow{2}{*}{2 noda } & 0,09 & +++ \\
\hline & & & 0,17 & ++ \\
\hline
\end{tabular}

*Eluen : kloroform : etil asetat (9:1)

Keterangan : +++: Intensitas noda tinggi (gelap); ++: Intensitas noda sedang (sedang); +: Intensitas noda rendah (pudar) 

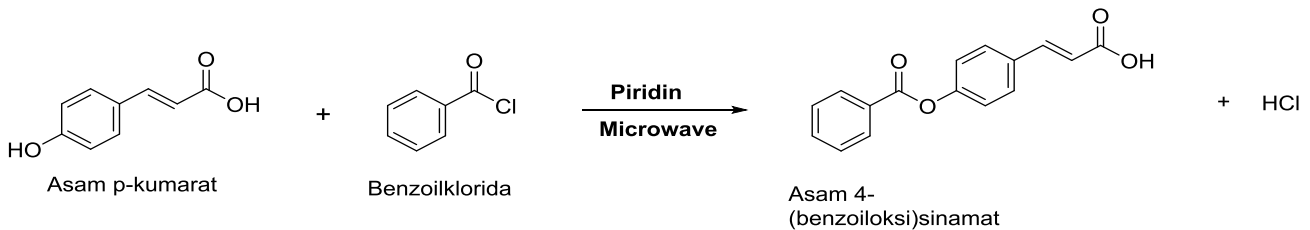

Gambar 2. Sintesis asam 4-(benzoiloksi)sinamat

Sintesis yang dilakukan pada daya 360 Watt sampling ke 2 x 30 detik, menunjukkan bahwa noda dari zat baru telah hilang akan tetapi noda dari asam $p$ kumarat dan asam benzoat memiliki intensitas tinggi. Hal tersebut berarti bahwa pada kondisi tersebut, zat baru yang dihasilkan pada kondisi tersebut telah mengalami degradasi. Oleh karena itu, membutuhkan metode KLT-Densitometri untuk mengetahui waktu reaksi yang menghasilkan persentase hasil sintesis yang paling besar.

Hasil uji KLT-Densitometri senyawa hasil sintesis dapat dilihat pada Tabel 2. Berdasarkan Tabel 2, dapat diketahui bahwa rata-rata persentase hasil reaksi terbesar didapatkan pada daya 270 Watt dengan waktu $2 \times 30$ detik. Pada sintesis dengan daya 360 Watt pada waktu 1 x 30 detik menunjukkan bahwa persentase hasil dari zat baru telah menurun.

Hal tersebut dapat terjadi karena penggunaan daya 360 Watt memberikan energi yang terbesar, sehingga energi panas terbentuk secara berlebihan. Panas yang berlebih tersebut dapat menyebabkan zat baru yang telah terbentuk mengalami degradasi menjadi asam kumarat dan asam benzoat kembali.

Untuk mengetahui apakah terdapat perbedaan bermakna pada persentase hasil sintesis dari ketiga daya tersebut, maka digunakan uji statistika One Way Anova menggunakan aplikasi IBM SPSS Statistics 24. Berdasarkan uji statistik tersebut $(\alpha=0,05)$, diketahui bahwa terdapat perbedaan bermakna $(p=0.005)$ persentase hasil antara penggunaan daya 270 Watt dengan daya 180 Watt.

Tabel 2. Hasil uji KLT-densitometri senyawa hasil sintesis

\begin{tabular}{|c|c|c|c|c|c|}
\hline \multirow{2}{*}{$\begin{array}{c}\text { Daya } \\
\text { (Watt) }\end{array}$} & \multirow{2}{*}{$\begin{array}{l}\text { Waktu } \\
\text { (detik) }\end{array}$} & \multicolumn{4}{|c|}{ Persentase Hasil Reaksi (\%) } \\
\hline & & Replikasi 1 & Replikasi 2 & Replikasi 3 & Rata-rata \\
\hline \multirow{4}{*}{180} & $0 \times 30$ & 46,8 & 46,5 & 47,2 & $46,8 \pm 0,4$ \\
\hline & $1 \times 30$ & 49,3 & 49,4 & 49,1 & $49,3 \pm 0,2$ \\
\hline & $2 \times 30$ & 56,1 & 56,2 & 57,5 & $56,6 \pm 0,8$ \\
\hline & $3 \times 30$ & 48,4 & 47,9 & 48,6 & $48,3 \pm 0,4$ \\
\hline \multirow{4}{*}{270} & $0 \times 30$ & 54,1 & 53,5 & 56,3 & $54,6 \pm 1,5$ \\
\hline & $1 \times 30$ & 57,7 & 57,5 & 60,2 & $58,5 \pm 1,5$ \\
\hline & $2 \times 30$ & 60,7 & 60,2 & 63,2 & $61,4 \pm 1,8$ \\
\hline & $3 \times 30$ & 46,8 & 46,7 & 48,9 & $47,5 \pm 1,2$ \\
\hline \multirow{2}{*}{360} & $0 \times 30$ & 53,5 & 53,9 & 55,1 & $54,2 \pm 0,8$ \\
\hline & $1 \times 30$ & 47,5 & 47,2 & 48,4 & $47,7 \pm 0,6$ \\
\hline
\end{tabular}

*Eluen yang digunakan untuk KLT adalah kloroform : etil asetat (9:1)

Hasil analisis statistik juga menunjukkan signifikansi $(p)=0,001$, antara persentase hasil pada daya 270 Watt dengan daya 360 Watt sebesar Nilai $\mathrm{p}<$ 0,05 ini menyatakan bahwa terdapat perbedaan bermakna antara persentase hasil sintesis pada daya 270 Watt dan pada daya 360 Watt. Sedangkan nilai signifikansi (p) yang didapatkan antara persentase hasil pada penggunaan daya 180 Watt dengan daya 360 Watt adalah 0,088 . Nilai $p>0,05$ menyatakan bahwa tidak terdapat perbedaan bermakna antara persentase hasil sintesis pada daya 180 Watt dan 360 Watt.
Setelah diketahui nilai persentase hasil terbesar, dilakukan proses pemisahan dengan kromatografi kolom. Senyawa hasil sintesis yang telah dipisahkan dengan kromatografi kolom dilakukan uji kemurnian dengan menggunakan uji titik lebur dan uji kemurnian dengan metode KLT.

Hasil uji titik lebur yang didapatkan yaitu jarak lebur yang didapatkan untuk senyawa hasil sintesis sebesar $121-123^{\circ} \mathrm{C}$ sedangkan jarak lebur asam $p$ kumarat sebesar $193-194^{\circ} \mathrm{C}$. Nilai jarak lebur senyawa hasil sintesis lebih rendah dari asam kumarat karena 
pada senyawa hasil sintesis hanya memungkinkan terjadinya ikatan hidrogen intermolekuler pada gugus karboksilat. Sedangkan pada asam kumarat, ikatan hidrogen intermolekuler dapat terjadi pada gugus karboksilat dan gugus $-\mathrm{OH}$ fenolik sehingga ikatan intermolekul asam $p$-kumarat lebih besar dan nilai titik leburnya lebih tinggi.

Hasil uji kemurnian dengan metode KLT dilakukan dengan menggunakan tiga eluen berbeda. Pada eluen kloroform : etil asetat (9:1) didapatkan 1 noda dengan nilai Rf sebesar 0,88. Pada eluen nheksana : etil asetat : asam formiat (19:20:1) didapatkan 1 noda dengan nilai Rf sebesar 0,80. Pada eluen kloroform : etil asetat : metanol (50:50:1) didapatkan 1 noda dengan nilai $\mathrm{Rf}$ sebesar 0,91.

Setelah dilakukan uji kemurnian, dilanjutkan dengan identifikasi struktur untuk memastikan bahwa senyawa yang terbentuk adalah asam 4benzoiloksisinamat. Identifikasi struktur yang dilakukan antara lain dengan menggunakan spektrofotometri UV-Vis, FT-IR, dan spektrometri ${ }^{1} \mathrm{H}-$ NMR.

Analisis menggunakan spektrofotometri UV-Vis untuk mengetahui pola spektrum dan panjang gelombang senyawa (Solomon dkk., 2016). Panjang gelombang maksimum asam kumarat sebagai bahan awal adalah $310 \mathrm{~nm}$ dan untuk asam 4benzoiloksisinamat adalah $285 \mathrm{~nm}$. Hal tersebut menunjukkan bahwa terjadi pergeseran panjang gelombang menjadi lebih pendek (hipsokromik).

Terjadinya pergeseran panjang gelombang maksimum ( $\lambda$ max.) ini dikarenakan gugus auksokrom -OH pada asam $p$-kumarat telah berubah menjadi gugus ester yang mana gugus karbonil dalam ester tersebut merupakan suatu gugus kromofor yang memiliki transisi $\mathrm{n} \rightarrow \pi^{*}$ pada $280-290 \mathrm{~nm}$ dan transisi $\pi \rightarrow \pi^{*}$ pada $188 \mathrm{~nm}$ (Pavia dkk., 2015). Adanya perbedaan panjang gelombang dan perbedaan pola spektrum keduanya menunjukkan bahwa zat hasil sintesis berbeda dengan asam p-kumarat.

Analisis menggunakan spektrofotometri FT-IR bertujuan untuk mengetahui adanya gugus-gugus fungsi apa saja yang terdapat dalam suatu senyawa (Solomon dkk., 2016). Hasil spektrum inframerah dari senyawa asam $p$-kumarat menunjukkan adanya serapan -OH fenolik pada $3380 \mathrm{~cm}^{-1}, \mathrm{C}=\mathrm{O}$ karboksilat pada $1671 \mathrm{~cm}^{-1}, \mathrm{C}-\mathrm{O}$ pada $1243 \mathrm{~cm}^{-1}, \mathrm{C}=\mathrm{C}$ aromatis pada $1510 \mathrm{~cm}^{-1}, \mathrm{C}-\mathrm{H}$ pada $832 \mathrm{~cm}^{-1}, \mathrm{C}=\mathrm{C}$ alkena pada 1627 $\mathrm{cm}^{-1}$, dan C-H pada $2924 \mathrm{~cm}^{-1}$.

Hasil spektrum inframerah senyawa asam 4benzoiloksisinamat dengan katalis piridina menunjukkan serapan $-\mathrm{OH}$ karboksilat pada $3444 \mathrm{~cm}^{-1}$, $\mathrm{C}=\mathrm{O}$ karboksilat pada $1716 \mathrm{~cm}^{-1}, \mathrm{C}-\mathrm{O}$ pada $1269 \mathrm{~cm}^{-1}$, $\mathrm{C}=\mathrm{C}$ aromatis pada $1506 \mathrm{~cm}^{-1}, \mathrm{C}-\mathrm{H}$ pada $859 \mathrm{~cm}^{-1}$, $\mathrm{C}=\mathrm{C}$ alkena pada $1639 \mathrm{~cm}^{-1}, \mathrm{C}-\mathrm{H}$ pada $2924 \mathrm{~cm}^{-1}$, dan $\mathrm{C}=\mathrm{O}$ ester pada $1736 \mathrm{~cm}^{-1}$.

Hasil identifikasi dengan spektrofotometri FT-IR menunjukkan bahwa terdapat perbedaan gugus fungsi antara senyawa hasil sintesis dengan bahan awal asam p-kumarat. Pada senyawa hasil sintesis dengan ditemukan adanya tambahan gugus karbonil dari ester, sedangkan pada senyawa awal asam $p$-kumarat tidak ditemukan gugus tersebut. Selain itu pita serapan tajam dari gugus $-\mathrm{OH}$ fenolik yang ada pada asam $p$-kumarat telah berubah menjadi pita serapan yang landai dengan intensitas sedang pada senyawa hasil sintesis. Sehingga berdasarkan hasil spektrum inframerah tersebut dapat disimpulkan bahwa senyawa hasil sintesis berbeda dengan senyawa awal.

Identifikasi senyawa hasil sintesis dengan spektrometer dilakukan dengan menggunakan pelarut $\mathrm{CDCl}_{3}$. Pada hasil spektrum ${ }^{1} \mathrm{H}-$ NMR ditemukan adanya 12 proton, antara lain proton dari asam karboksilat pada pergeseran kimia 10,0 ppm (singlet) dengan jumlah proton $1 \mathrm{H}$.

Proton dari alkena didapatkan pada pergeseran kimia 6,43 ppm (doblet) dengan tetapan kopling $(J=$ $16 \mathrm{~Hz}$ ) dengan jumlah proton $1 \mathrm{H}$ dan pada pergeseran kimia 7,52 ppm (doblet) dengan tetapan kopling $(J=$ $16 \mathrm{~Hz}$ ) dengan jumlah proton $1 \mathrm{H}$. Berdasarkan Pavia dkk. (2015), diketahui bahwa gugus alkena dengan isomer cis memiliki nilai tetapan kopling sebesar 6 - 15 $\mathrm{Hz}$, sedangkan untuk isomer trans sebesar $11-18 \mathrm{~Hz}$. Tetapan kopling gugus alkena yang diperoleh dari spektrum ${ }^{1} \mathrm{H}-\mathrm{NMR}$ sebesar $16 \mathrm{~Hz}$ yang menunjukkan bahwa senyawa yang terbentuk dalam posisi trans.

Proton dari cincin aromatis I didapatkan pada pergeseran kimia 7,53 ppm (doblet, $2 \mathrm{H}$ ) dan 7,59 ppm (doblet, 2H) dengan tetapan kopling $(J=8,8 \mathrm{~Hz})$. Berdasarkan Pavia dkk. (2015), menyatakan bahwa proton yang memiliki pasangan atom hidrogen pada posisi ortho memiliki nilai tetapan kopling sebesar 6 $10 \mathrm{~Hz}$. Tetapan kopling dari kedua proton pada cincin aromatis I sebesar $8,8 \mathrm{~Hz}$ yang menunjukkan bahwa kedua proton tersebut memiliki posisi ortho. Proton dari cincin aromatis II didapatkan pada pergeseran kimia 8,21 ppm (doblet, $2 \mathrm{H}$ ) dengan tetapan kopling $(J$ = 9,2 Hz), dan geseran kimia 7,67-7,77 ppm (multiplet, $3 \mathrm{H})$. Pergeseran kimia dari proton-proton yang didapatkan pada spektrum ${ }^{1} \mathrm{H}-\mathrm{NMR}$ tersebut mengarahkan bahwa senyawa yang terbentuk adalah asam trans-4-benzoiloksisinamat. 


\section{KESIMPULAN}

Kondisi optimum sintesis asam 4benzoiloksisinamat dengan katalis piridin dan menggunakan metode iradiasi gelombang mikro adalah pada power iradiasi 270 Watt selama reaksi $2 \times 30$ detik.

\section{UCAPAN TERIMA KASIH}

Ucapan terima kasih yang sebesar-besarnya disampaikan kepada Universitas Airlangga yang telah membiayai penelitian ini dari dana PTUPT 2017-2018.

\section{DAFTAR PUSTAKA}

Ameta, S. C., Punjabi, P. B., Ameta, R. \& Ameta, C. (2015). Microwave-Assisted Organic Synthesis: A Green Chemical Approach. $1^{\text {st }}$ Ed. Canada: Apple Academic Press Inc.

Carey, F. A. \& Sundberg, R. J. (2001). Advanced Organic Chemistry, Part B: Reaction and Synthesis (4th Ed.). New York: Kluwer Academic/Plenum Publishers.

Caseley, E. A., Muench, S. P., Baldwin, S. A., Simmons, K., Fishwick, C. W. \& Jiang, L. H. (2015). Docking of Competitive Inhibitors to the P2X7 Receptor Family Reveals Key Differences Responsible for Changes in Response between Rat and Human. Bioorganic \& Medicinal Chemistry Letters; 25; 3164-3167.

Ekowati, J., Diyah, N. W., Miatmoko, A. \& Hamid, I. S. (2017). Rekayasa Senyawa Fenolik Turunan Asam Sinamat sebagai Anti-platelet dan Antikanker. Laporan Penelitian; PTUPT Universitas Airlangga, Surabaya.
Grundas, S. (2011). Advances in Induction and Microwave Heating of Mineral and Organic Materials ( $1^{\text {st }}$ Ed). Rijeka: InTech.

Neophytou, N., Leonis, G., Stavrinoudakis, N., Simcic, M., Grdadolnik, S. G., Papavassilopoulou, E., Michas, P., Moutevelis-Minakakis, P., Papadupoulos, M. G., Zing, M. \& Mavromoustakos, T. (2011). Docking and Molecular Dynamics Calculations of Pyrrolidinone Analog MMK16 Bound to COX and LOX Enzymes. Molecular Informatics; 30; 473-486.

Pavia, D. L., Lampman, G. M., Kriz, G. S. \& Vyvyan, J. R. (2015). Introduction to Spectroscopy (5th Ed). Stanford: Cengage Learning.

Putra, G. S., Widiyana, A. P., Muchlashi, L. A., Sulistyowaty, M. I., Ekowati, J. \& Budiati, T. (2017). The Influence of Ratio Pyridine and Triethylamine Catalysts on Synthesis 2-PhenylBenzo[D] [1,3] Oxazine-4-On Derivatives. Journal of Chemical and Pharmaceutical Research; 9; 73-80.

Quellette, R. J. \& Rawn, J. D. (2014). Organic Chemistry: Structure, Mechanism, and Synthesis (1st Ed). San Diego: Elsevier.

Solomon, T. W. G., Fryhle, C. B. \& Snyder, S. A. (2016). Organic Chemistry (12th Ed). New Jersey: John Wiley and Sons, Inc.

Zhao, Y., Liu, J., Zeng, C., Li, X. \& Zhao, J. (2016). Anti-Inflammatory Effects of $p$-Coumaric Acid in LPS-Stimulated RAW264.7 Cells: Involvement of NF- $\mathrm{\kappa B}$ and MAPKs Pathways. Medical Chemistry; 6; 327-330. 